УДК 676.017

DOI: $10.37482 / 0536-1036-2021-5-174-184$

\title{
REGULATING THE DEFORMATION PROPERTIES OF PAPER BY VARYING THE DEGREE OF ITS ANISOTROPY
}

\author{
Didier Rech', Researcher \\ Anastasiia N. Potasheva ${ }^{2}$ Postgraduate Student; ResearcherID: AAP-9396-2021, \\ ORCID: https://orcid.org/0000-0002-8216-3844 \\ Yakov V. Kazakov², Doctor of Engineering, Prof.; ResearcherID: J-4634-2012, \\ ORCID: https://orcid.org/0000-0001-8505-5841
}

1Techpap SAS, B.P. 251, Cedex 9, Grenoble, 38044, France; e-mail: didier.rech@techpap.com ${ }^{2}$ Northern (Arctic) Federal University named after M.V. Lomonosov, Naberzhnaya Severnoy Dviny, 17, Arkhangelsk, 163002, Russian Federation; e-mail: a.romanova@narfu.ru, j.kazakov@narfu.ru

Original article / Received on March 20, 2020 / Accepted on June 8, 2020

\begin{abstract}
Mechanical properties are crucial in assessing the paper quality. Deformation and strength properties of paper are determined by the strength and stiffness of the interfiber and intermolecular hydrogen bonds. The contribution ratio of interfiber and intermolecular hydrogen bonds to the strength of paper can be changed by adjusting the degree of its anisotropy. The article presents the results on a study of the deformation properties of laboratory anisotropic paper samples from kraft bleached softwood pulp with a beating degree of $30{ }^{\circ} \mathrm{SR}$. The samples had basic weight of $90 \mathrm{~g} / \mathrm{m}^{2}$ and the degree of stiffness anisotropy $T S I_{\mathrm{MD} / \mathrm{CD}}$ of 1.75-4.08. They were made by using Techpap SAS automatic dynamic handsheet former (Grenoble, France), with varying forming parameters - diameter of the nozzle, motion speed of the forming wire, and injecting speed of pulp. Deformation properties were determined by tensile test and processing of the stress-strain dependence $(\sigma-\varepsilon)$. The outcomes have shown that, an increase of the fiber orientation degree in paper structure by changing the forming parameters caused a change in the nature of the paper deformation under tension. Increasing the fiber orientation degree in the structure of paper made it possible to increase the strength by $55 \%$, tensile stiffness by $63 \%$ in the machine direction, while reducing the extensibility by $10 \%$. In the cross direction, it was possible to decrease tensile stiffness by $33 \%$, strength by $55 \%$, and increase the extensibility by $5 \%$. Anisotropy of tensile strength was 1.73-6.00. The greatest effect was obtained for the elasticity modulus in the pre-failure zone $E_{2}$ (2.8-38.6). It means that, fiber orientation had a key importance when large deformations in the samples took place. The established quantitative regularities allowed optimizing the values of the deformation and strength properties of paper, and their ratio in the machine direction and cross direction due to the variation of the forming parameters.

For citation: Rech D., Potasheva A.N., Kazakov Ya.V. Regulating the Deformation Properties of Paper by Varying the Degree of Its Anisotropy. Lesnoy Zhurnal [Russian Forestry Journal], 2021, no. 5, pp. 174-184. DOI: 10.37482/0536-1036-2021-5-174-184
\end{abstract}

Keywords: forming, FDA, fiber orientation, anisotropy, stiffness, strength.

This is an open access article distributed under the terms of the Creative Commons Attribution 4.0 International (CC BY 4.0) license • The authors declare that there is no conflict of interest 


\title{
РЕГУЛИРОВАНИЕ ДЕФОРМАЦИОННЫХ СВОЙСТВ БУМАГИ ПУТЕМ ВАРЬИРОВАНИЯ СТЕПЕНИ ЕЕ АНИЗОТРОПИИ
}

\author{
Д. Рёч ${ }^{1}$, науч. сотр. \\ A.H. Поташева ${ }^{2}$, асnиранm; ResearcherID: AAP-9396-2021, \\ ORCID: https://orcid.org/0000-0002-8216-3844 \\ Я.В. Казаков ${ }^{2}$, д-р техн. наук, проф.; ResearcherID: J-4634-2012, \\ ORCID: https://orcid.org/0000-0001-8505-5841 \\ 1Techpap SAS, a/я 251, Седекс 9, г. Гренобль, Франция, 38044; \\ e-mail: didier.rech@techpap.com \\ ${ }^{2}$ Северный (Арктический) федеральный университет им. М.В. Ломоносова, наб. Се- \\ верной Двины, д. 17, г. Архангельск, Россия, 163002; e-mail: a.romanova@narfu.ru; \\ j.kazakov@narfu.ru
}

Оригинальная статья / Поступила в редакциию 20.03.20 / Принята к печати 08.06.20

Аннотация. Механические свойства являются ключевыми при оценке качества бумаги и определяются прочностью и жесткостью межволоконных и межмолекулярных водородных связей. Вклад разных видов связей в прочность образца возможно менять регулированием степени анизотропии бумаги. Исследованы деформационные свойства лабораторных анизотропных образцов бумаги из беленой хвойной целлюлозы при

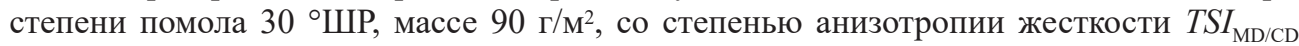
(отношение индексов жесткости при растяжении, $T S I_{\mathrm{MD}}$ к $T S I_{\mathrm{CD}}$ ) 1,75...4,08. Образцы были изготовлены на динамическом листоотливном аппарате TechPap SAS (г. Гренобль, Франция) при переменных параметрах отлива: скорости сетки, скорости струи, диаметре форсунки. Деформационные и прочностные свойства определены испытанием на растяжение с получением зависимости «напряжение-деформация». Показано, что увеличение степени ориентации волокна за счет варьирования параметров отлива делает прочность в машинном направлении больше на 55 \%, жесткость при растяжении - на $63 \%$, снижает растяжимость на $10 \%$; в поперечном направлении возможно уменьшение жесткости при растяжении на $33 \%$, прочности - на $55 \%$, увеличение растяжимости на 5 \%. Анизотропия прочности при растяжении составила 1,73...6,00. Наибольший эффект получен для модуля упругости в области предразрушения - 2,8...38,6, т. е. ориентация волокна имеет ключевое значение при больших деформациях образцов. Установленные количественные закономерности позволяют оптимизировать величины деформационных и прочностных показателей бумаги и их соотношение в машинном и поперечном направлениях за счет варьирования параметров отлива.

Для цитирования: Rech D., Potasheva A.N., Kazakov Ya.V. Regulating the Deformation Properties of Paper by Varying the Degree of Its Anisotropy // Изв. вузов. Лесн. журн. 2021. № 5. C. 174-184. DOI: 10.37482/0536-1036-2021-5-174-184

Ключевые слова: формование, динамический листоотливный аппарат, ориентация волокон, анизотропия, жесткость, прочность.

\section{Introduction}

Strength and deformation characteristics are key markers to evaluate the quality of pulp and paper products. Achieving the requested level of consumer properties for these materials is closely related to the process of forming their structure. Thus, the prediction of the deformation behavior of paper and cardboard at the stage of modeling their structure has a particular scientific, economic and practical interest [4]. 
Paper is a material of anisotropic, discrete fibrous net-like structure [1, 10]. The strength of structure is formed by hydrogen bonds (HB). The deformation and strength properties of paper are determined by the strength and stiffness of interfiber and intermolecular HB. Intermolecular bonds determine the intrinsic strength of fibers. The intensity of interfiber bonds is regulated by beating the plant fibers at the stage of refining. The contribution ratio of interfiber and intermolecular HB to the strength of a paper sample can be changed through adjusting the degree of paper anisotropy $[5,7]$.

The modern scientific approach and the latest engineering technologies make it possible to model the structure of pulp and paper materials, to test and analyze their properties at a stage of laboratory research. Moreover, they give a chance to obtain anisotropic laboratory samples with characteristics like or similar to those of final products of papermaking and cardboard machines (PM and CM, respectively). As a result, it was found that the degree of anisotropy of the sample has a significant effect on the paper mechanical properties. However, for each study using laboratory equipment, it is necessary to select its own conditions for making samples in order to achieve compliance of properties with industrial paper [3, 17, 20,21].

Techpap SAS laboratory equipment (France), operating in the Laboratory of modeling and researching compositions of paper and cardboard of the Innovative Facilities Engineering and Innovation Center "Advanced Northern Bioresources Processing Technologies" based at the Northern (Arctic) Federal University named after M.V. Lomonosov (NArFU), provides an opportunity to implement stage by stage the full range of activities to study anisotropic paper and cardboard samples. The complex enables to bring the properties of laboratory samples closer to those of real products $[18,21]$.

The anisotropy of the paper structure determines the anisotropy of its deformation and strength properties $[1,4,11]$. The direction of the preferred fibers orientation in the sample largely determines its response to the application of an external load [8]. The difference in the properties of such specimens is most clearly determined by the shape of the stress-strain curves $[4,6]$. When modeling the structure and properties of a fibrous material based on discrete fibers, taking into account anisotropy is a necessary condition for obtaining adequate results $[2,13,19]$. The correspondence of the stress-strain dependence of the model sample with the experimental data is the most frequent proof of the efficiency of the proposed modeling method $[2,13]$.

The aim of this work is to establish quantitative regularities that connect the parameters of the paper forming on the dynamic sheet former and the degree of anisotropy of laboratory paper samples, which make it possible to control the values of their deformation and strength properties, including optimizing the ratio of these values in the machine direction (MD) and cross direction (CD).

\section{Research objects and methods}

Techpap SAS laboratory equipment includes the automatic dynamic handsheet former (FDA) (fig. 1), laboratory press (fig. 2) and dryer (fig. 3). The complex closely simulates the work of industrial paper machines and produces rectangular sheets with dimensions up to $25 \times 90 \mathrm{~cm}$ with the motion speed of the forming wire from 700 to $1300 \mathrm{~m} / \mathrm{min}$. It allows researchers to obtain anisotropic paper and cardboard samples and maximize their properties to those of the products of PM and CM. 
The rectangular form of handsheets has great advantages when carrying out analyses under production conditions as well as research developments. Such handsheets can be calendered and coated. Their size allows making a big number of tests for a one sheet. In addition, it is possible to produce multi-layer handsheets and handsheets with a large range of basis weight $[5,7]$.

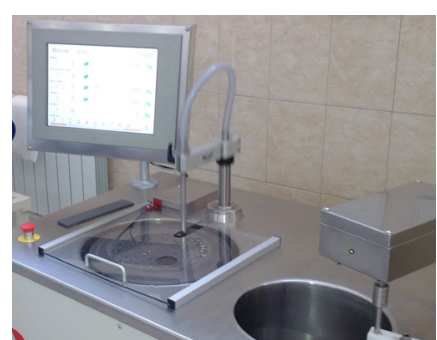

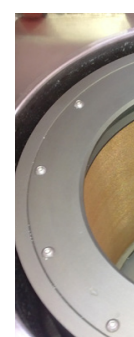

(o

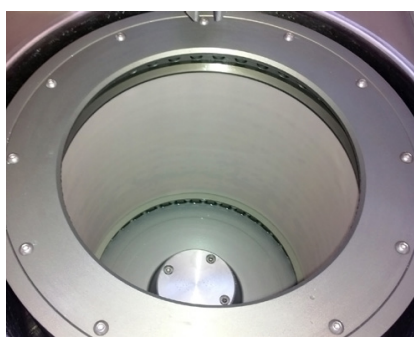

Fig. 1. The elements of the FDA, Techpap SAS: $a$ - forming device and its control panel; $b-$ cylindrical jar with the forming wire inside before testing; $c$ - finished wet web of a handsheet on the wire

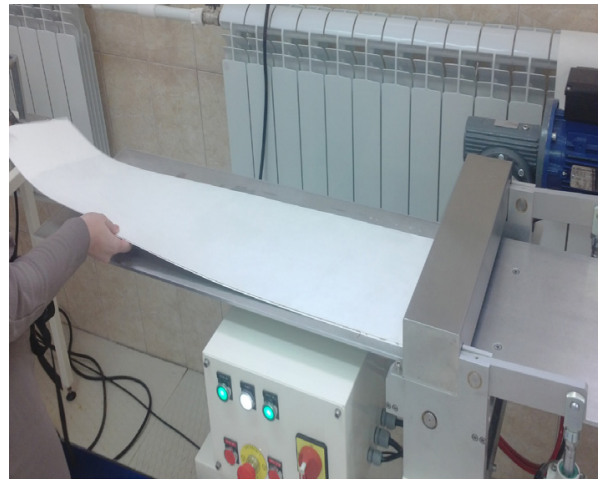

Fig. 2. Pressing the handsheet by means of a pneumatic single-drum press

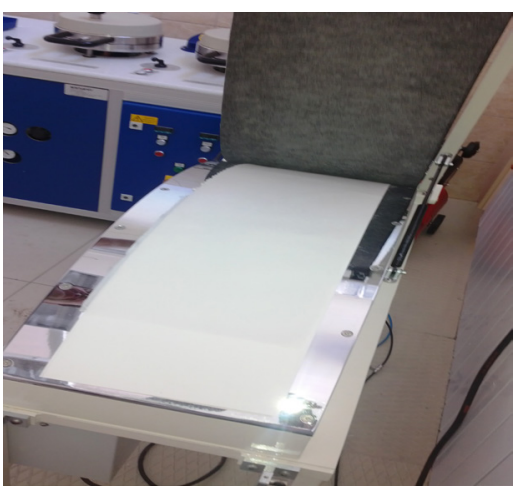

Fig. 3. Drying the sheet by means of a temperature controlled laboratory dryer

The principle of dynamic sheet forming is as follows. The main part of the FDA is a cylindrical jar rotating around a vertical axis (fig. 4). The jar has a perforated wall. Water enters into the jar centrifugally through the nozzle and forms a vertical water wall when the rotation speed is over $700 \mathrm{rpm}$. The water wall covers the perforated wall and moves along with it [15].

The forming wire is installed on the inner side of the perforated wall before testing. Together they are covered with the water wall of $5 \mathrm{~mm}$ thick. The injector nozzle is fixed on a delivery tube at a certain angle. The nozzle sweeps vertically up and down evenly distributing a diluted fibrous mass onto the water wall under pressure. The fibers go through the water wall to the wire forming a layer of fibrous mass. It takes place until a given basis weight is reached.

Upon completion of fiber injection water is removed from the jar. The layer of a wet fibrous mass remains on the wire. As the jar stops its rotating, the handsheet is taken out from the jar together with the wire. To separate a wet handsheet from the forming wire they are covered by filter paper and rolled with a roller on top. 


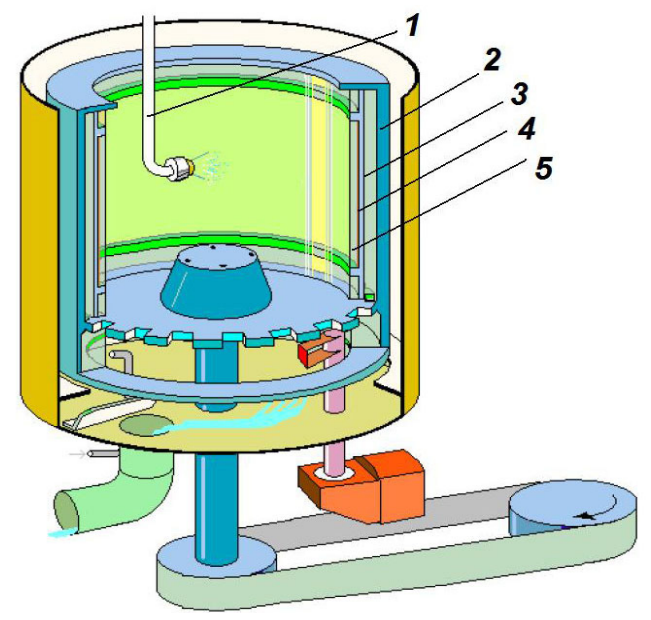

Fig. 4. Structural units of the FDA forming device: 1 - sweeping flat jet nozzle; 2 - forming jar; 3 perforated cylinder; 4 - forming wire; 5 - water wall

The handsheet undergoes pressing and drying between layers of filter paper. It provides to form a handsheet similar to a sheet obtained by an industrial method. Moreover, adjusting the ratio of the speed of nozzle and of wire motion makes it possible to obtain laboratory handsheets with varying degree of anisotropy.

To model the anisotropic macrostructure of paper samples we varied the forming parameters of the FDA such as circumferential motion speed of the forming wire, the pressure of fibrous mass injection on the wire through the nozzle by changing the speed of the feeding pump, and the diameter of the nozzle. Thus, we adjusted the degree of paper anisotropy by changing the ratio of jet and wire speed.

An additional factor was the duration of the forming process that was increasing due to a smaller diameter of the nozzle. Consequently, fibers near the forming wire were subjected to a supplementary orientation in MD.

Preliminary experiments have shown [7] that in order to increase the degree of anisotropy, it is necessary to increase the rotation speed of the forming drum and reduce the pressure in the pump feeding the pulp to the wire. Reducing the diameter of the nozzle orifice also increases the jet speed. However, the final result depends on the furnish composition and the basic weight of the samples. And they must be specified in each individual case.

The forming parameters we used to make laboratory paper samples from kraft softwood bleached pulp with a beating degree of $30^{\circ} \mathrm{SR}$ are given in table 1 . The values of the FDA process parameters were chosen close to the average and extreme allowable according to the technical characteristics of the FDA. A total of 6 paper samples were made and analyzed. This made it possible to obtain a series of paper samples with different properties. The obtained handsheets had weight of $90 \mathrm{~g} / \mathrm{m}^{2}$, dimensions of $25 \times 90 \mathrm{~cm}$ and different degree of anisotropy.

In order to evaluate deformation properties of laboratory paper samples we carried out the uniaxial tensile tests and mathematically processed the obtained "stress-strain" dependence $(\sigma-\varepsilon)[10,12]$. The test with a uniaxial static loading was conducted by means of the laboratory test complex at a loading rate of $5 \mathrm{~cm} / \mathrm{min}$. 
Table 1

The parameters of the FDA used for modeling the structure of laboratory handsheets

\begin{tabular}{|l|c|c|c|c|c|c|}
\hline \multirow{2}{*}{ Regulated parameter } & \multicolumn{5}{|c|}{ Parameter value for modes } \\
\cline { 2 - 7 } & $\mathrm{R} 1$ & $\mathrm{R} 2$ & $\mathrm{R} 3$ & $\mathrm{R} 4$ & $\mathrm{R} 5$ & $\mathrm{R} 6$ \\
\hline $\begin{array}{l}\text { The rotation speed of } \\
\text { the forming wire of the } \\
\text { FDA v, m/min }\end{array}$ & 800 & 800 & 950 & 1000 & 1200 & 1350 \\
\hline $\begin{array}{l}\text { The pump revolution } \\
\text { feeds the mass onto the } \\
\text { wire } p, \mathrm{rpm}\end{array}$ & 1400 & 1400 & 1200 & 900 & 600 & 300 \\
\hline $\begin{array}{l}\text { Nozzle grade } d \text { (size, } \\
\text { mm) }\end{array}$ & $\begin{array}{c}2504 \\
(1.0 \times 1.0)\end{array}$ & $\begin{array}{c}2510 \\
(2.0 \times 1.8)\end{array}$ & $\begin{array}{c}2510 \\
(2.0 \times 1.8)\end{array}$ & $\begin{array}{c}2506 \\
(1.8 \times 1.2)\end{array}$ & $\begin{array}{c}2504 \\
(1.0 \times 1.0)\end{array}$ & $\begin{array}{c}2504 \\
(1.0 \times 1.0)\end{array}$ \\
\hline
\end{tabular}

The complex includes the vertical tensile testing machine "TEST SYSTEM 101 " and personal computer (PC) that are used according to the method [12] by applying the software [9]. To carry out the test we cut the paper samples into strips with a width of $1.5 \mathrm{~cm}$. Distance between jaws of tensile tester was $10.0 \mathrm{~cm}$.

\section{Research results and discussion}

On mill paper machines, in order to change the degree of paper anisotropy, the ratio of jet/wire speeds is changed. An increase in the lag of the pulp jet speed from the wire speed (efflux) leads to an increase in the degree of fiber orientation and an increase in anisotropy. Filtration begins as soon as the paper pulp comes into contact with the wire, and the duration of the drain is several seconds.

On the applied dynamic sheet former, the pulp is first pumped onto the moving wire for several minutes. And then quickly, in a few seconds, water is removed after the command of the operator. Thus, the laboratory conditions of formation are still different from the industrial ones, although they make it possible to obtain anisotropic samples.

A quantitative estimation of anisotropy degree was performed by several methods $[1,11]$. The most popular characteristic is stiffness anisotropy $T S I_{\mathrm{MD} / \mathrm{CD}}$ (the ratio of the tensile stiffness, $T S I_{\mathrm{MD}}$ by $T S I_{\mathrm{CD}}$ ) measured by the ultrasonic method using the L\&W TSO tester [14].

The variation of the forming modes presented in table 1 gave us a chance to obtain samples with $T S I_{\mathrm{MD} / \mathrm{CD}}$ values from 1.75 to 4.08 (table 2). In fact, for white paper grades produced by PM, $T S I_{\mathrm{MD} / \mathrm{CD}}$ values are usually from 2.3 to 3.0. Thus, we obtained samples with a greater range of $T S I_{\mathrm{MD} / \mathrm{CD}}$ values. Hence, we managed the task to make samples with different degree of anisotropy.

Additionally, the degree of fiber orientation $\lambda$ was determined in accordance with the method $[8,16]$ (table 2). The $\lambda$ values ranged from 0.51 to 0.65 and, as we can see, correlated well with the $T S I_{\mathrm{MD} / \mathrm{CD}}$ values.

The physical characteristics of the obtained paper samples such as thickness $\delta \mu \mathrm{m}$, density $\rho, \mathrm{g} / \mathrm{cm}^{3}$, and porosity, $\mathrm{mL} / \mathrm{min}$, were determined (table 2 ). It has been found that the forming conditions also affected the density of the fibrous structure while forming on the wire. The extreme values of the degree of anisotropy caused a decrease of thickness and an increase of density, not exceeding $8 \%$. 
Deformation properties of the obtained anisotropic paper samples

\begin{tabular}{|c|c|c|c|c|c|c|c|c|}
\hline \multirow{2}{*}{ Characteristic } & \multirow{2}{*}{ Units } & \multirow{2}{*}{ Direction } & \multicolumn{6}{|c|}{ Forming mode } \\
\hline & & & $\mathrm{R} 1$ & $\mathrm{R} 2$ & R3 & $\mathrm{R} 4$ & R5 & R6 \\
\hline Thickness, $\delta$ & $\mu \mathrm{m}$ & & 115 & 114 & 122 & 121 & 118 & 112 \\
\hline Density, $\rho$ & $\mathrm{g} / \mathrm{cm}^{3}$ & & 0.743 & 0.740 & 0.719 & 0.717 & 0.737 & 0.752 \\
\hline Porosity & $\mathrm{mL} / \mathrm{min}$ & & 134 & 173 & 143 & 166 & 149 & 168 \\
\hline $\begin{array}{c}\text { Degree } \\
\text { of fiber } \\
\text { orientation, } \lambda\end{array}$ & - & & 0.511 & 0.533 & 0.601 & 0.615 & 0.636 & 0.650 \\
\hline \multirow{3}{*}{$\begin{array}{c}\text { Tensile } \\
\text { stiffness } \\
\text { index }(T S I)\end{array}$} & \multirow{2}{*}{$\mathrm{Nm} / \mathrm{kg}$} & MD & 13.60 & 16.08 & 18.41 & 19.03 & 19.73 & 19.95 \\
\hline & & $\mathrm{CD}$ & 7.75 & 7.84 & 5.59 & 5.27 & 5.01 & 4.88 \\
\hline & - & $\mathrm{MD} / \mathrm{CD}$ & 1.75 & 2.05 & 3.29 & 3.61 & 3.93 & 408 \\
\hline \multirow{3}{*}{$\begin{array}{l}\text { Breaking } \\
\text { length, } L\end{array}$} & \multirow{2}{*}{$\mathrm{m}$} & MD & 11750 & 14200 & 16900 & 17300 & 18100 & 17750 \\
\hline & & $\mathrm{CD}$ & 6850 & 7450 & 4100 & 3600 & 3200 & 3050 \\
\hline & - & $\mathrm{MD} / \mathrm{CD}$ & 1.72 & 1.91 & 4.12 & 4.81 & 5.66 & 5.82 \\
\hline \multirow{3}{*}{$\begin{array}{c}\text { Initial } \\
\text { modulus of } \\
\text { elasticity, } E_{1}\end{array}$} & \multirow{2}{*}{$\mathrm{MPa}$} & MD & 6260 & 7380 & 8210 & 8600 & 9230 & 9800 \\
\hline & & $\mathrm{CD}$ & 3280 & 3572 & 2430 & 2190 & 2070 & 2120 \\
\hline & - & $\mathrm{MD} / \mathrm{CD}$ & 1.91 & 2.07 & 3.38 & 3.93 & 4.46 & 4.62 \\
\hline \multirow{3}{*}{$\begin{array}{l}\text { Tensile en- } \\
\text { ergy absorp- } \\
\text { tion }(T E A)\end{array}$} & \multirow{2}{*}{$\mathrm{J} / \mathrm{m}^{2}$} & $\mathrm{MD}$ & 175 & 204 & 257 & 252 & 262 & 250 \\
\hline & & $\mathrm{CD}$ & 169 & 187 & 126 & 115 & 97 & 92 \\
\hline & - & $\mathrm{MD} / \mathrm{CD}$ & 1.04 & 1.09 & 2.04 & 2.19 & 2.70 & 2.72 \\
\hline \multirow{3}{*}{$\begin{array}{l}\text { Limit of } \\
\text { elasticity, } \sigma_{1}\end{array}$} & \multirow{2}{*}{$\mathrm{MPa}$} & $\mathrm{MD}$ & 16.65 & 20.69 & 20.23 & 21.68 & 24.42 & 25.92 \\
\hline & & $\mathrm{CD}$ & 8.24 & 8.00 & 6.65 & 6.08 & 5.82 & 5.09 \\
\hline & - & $\mathrm{MD} / \mathrm{CD}$ & 2.02 & 2.59 & 3.04 & 3.57 & 4.20 & 5.09 \\
\hline \multirow{3}{*}{$\begin{array}{l}\text { Limit of } \\
\text { elastic defor- } \\
\text { mation, } \varepsilon_{1}\end{array}$} & \multirow{2}{*}{$\%$} & MD & 0.27 & 0.28 & 0.25 & 0.26 & 0.27 & 0.27 \\
\hline & & $\mathrm{CD}$ & 0.26 & 0.27 & 0.23 & 0.28 & 0.29 & 0.29 \\
\hline & - & $\mathrm{MD} / \mathrm{CD}$ & 1.19 & 1.04 & 1.09 & 0.93 & 0.93 & 0.93 \\
\hline \multirow{3}{*}{$\begin{array}{l}\text { Stress-at- } \\
\text { failure, } \sigma_{f}\end{array}$} & \multirow{2}{*}{$\mathrm{MPa}$} & MD & 87.2 & 104.1 & 116.7 & 122.4 & 132.6 & 135.2 \\
\hline & & $\mathrm{CD}$ & 50.5 & 55.3 & 30.3 & 26.0 & 23.3 & 22.5 \\
\hline & - & $\mathrm{MD} / \mathrm{CD}$ & 1.73 & 1.88 & 3.86 & 4.70 & 5.68 & 6.00 \\
\hline \multirow{3}{*}{$\begin{array}{l}\text { Strain-to- } \\
\text { failure, } \varepsilon_{f}\end{array}$} & \multirow{2}{*}{$\%$} & MD & 2.83 & 2.66 & 2.74 & 2.68 & 2.62 & 2.57 \\
\hline & & $\mathrm{CD}$ & 4.42 & 4.39 & 4.66 & 4.58 & 4.50 & 4.37 \\
\hline & - & $\mathrm{CD} / \mathrm{MD}$ & 1.56 & 1.65 & 1.70 & 1.71 & 1.72 & 1.70 \\
\hline \multirow{3}{*}{$\begin{array}{c}\text { Modulus of } \\
\text { elasticity in } \\
\text { the pre-failure } \\
\text { zone, } E_{2}\end{array}$} & \multirow{2}{*}{$\mathrm{MPa}$} & MD & 1620 & 2050 & 2350 & 2700 & 2880 & 3090 \\
\hline & & $\mathrm{CD}$ & 570 & 610 & 190 & 140 & 110 & 80 \\
\hline & - & $\mathrm{MD} / \mathrm{CD}$ & 2.84 & 3.36 & 12.37 & 19.29 & 26.18 & 38.63 \\
\hline
\end{tabular}



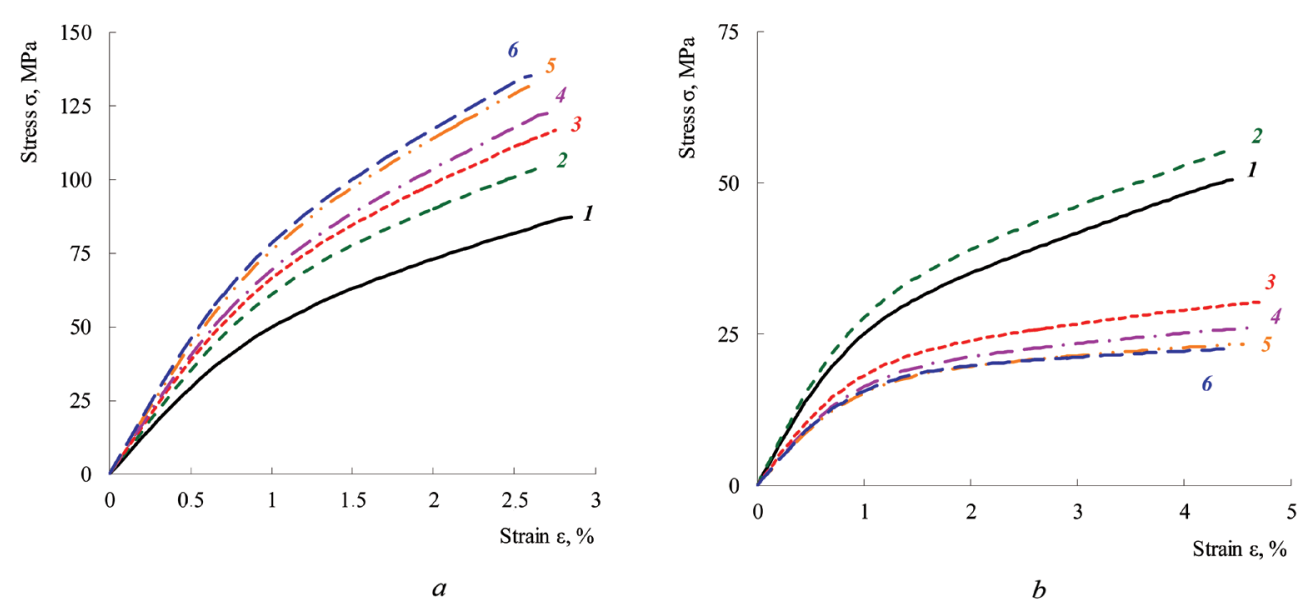

Fig. 5. The stress-strain curves for paper samples from kraft softwood bleached pulp: $a-\mathrm{MD}$; $b-\mathrm{CD} ; 1-6-$ modes of the forming process (table 1 )

In order to evaluate deformation properties of laboratory paper samples we carried out the uniaxial tensile tests and mathematically processed the obtained "stress-strain" dependence $(\sigma-\varepsilon)$, see fig. $5[6,12]$.

Fig. 5 shows the following: in the MD, with rose the degree of anisotropy, the curves $\sigma-\varepsilon$ went higher (strength increased) and had a greater steepness (stiffness increases), but their length decreased (elongation decreased). The curve for a sample with a $T S I_{\mathrm{MD} / \mathrm{CD}}$ value of less than 2 is quite different from the others - it goes much lower. For the rest of the samples, the change in the course of the curve corresponds to the change in the degree of anisotropy.

In the $\mathrm{CD}$, on the contrary, as the degree of anisotropy rose, the curves went lower and had their longer length. Accordingly, the strength and rigidity decreased, elongation increased. Here, too, for the sample with $T S I_{\mathrm{MD} / \mathrm{CD}}$ values of 1.75 and 2.05, they are quite different from the others - the curves are much higher than the others. For the rest of the samples, a change in the course of the curve corresponds to a change in the degree of anisotropy.

Thus, the change in the nature of the paper deformation under tension was clearly demonstrated. It was reflected in the values of the deformation and strength characteristics (table 2).

In this case, anisotropy of the tensile strength (1.73-6.00) was significantly higher than of the TSI stiffness measured by the ultrasonic method (1.75-4.08). The greatest effect was obtained for the elasticity modulus in the pre-failure zone $E_{2}(2.8-38.6)$. The fiber orientation had its key importance with large deformations of the samples. The smallest influence was on the anisotropy of the elastic strain limit (0.93-1.19).

With an increase in the degree of anisotropy, in the machine direction the breaking length of the paper increases by $51 \%$ (from $11750 \mathrm{~m}$ for samples with low anisotropy, to $17550 \mathrm{~m}$ for samples with high anisotropy). Elastic modulus increases by $56 \%$ (from 6260 to $9800 \mathrm{MPa}$ ), tensile energy absorption (TEA) - by $43 \%$ (from 175 to $250 \mathrm{~J} / \mathrm{m}^{2}$ ). The elastic limit increases by $56 \%$ (from 16.6 to $25.9 \mathrm{MPa}$ ). The limit of elastic deformation practically does not change and is $0.26-0.27 \%$. Strain at fracture is reduced by $9 \%$ (from 2.83 to $2.57 \%$ ). 


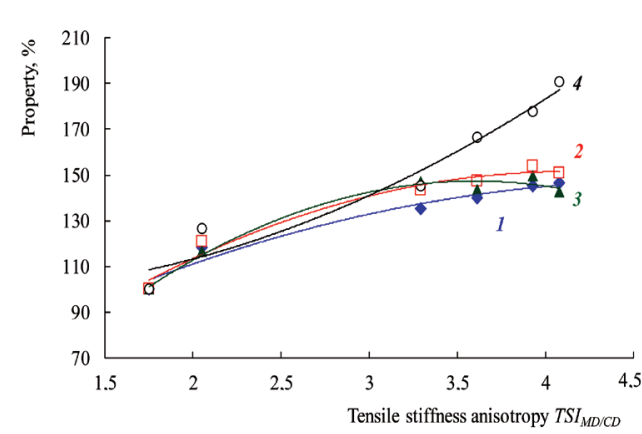

$a$

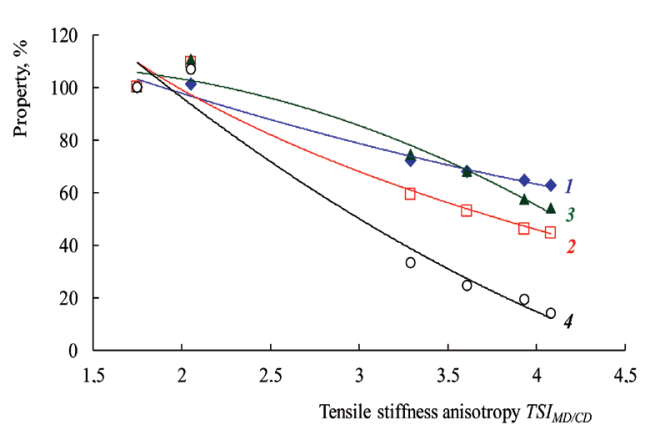

$b$

Fig. 6. Deformation and strength properties versus degree of anisotropy for hand-made samples: $a-\mathrm{MD} ; b-\mathrm{CD} ; 1-T S I ; 2-$ tensile strength; $3-T E A ; 4$ - modulus of elasticity in the pre-failure zone $E_{2}, \mathrm{MPa}$

In the $\mathrm{CD}$, the breaking length of the paper reduced by $55 \%$ (from $6800 \mathrm{~m}$ for samples with low anisotropy, to $3050 \mathrm{~m}$ for samples with high anisotropy). The elastic modulus decreased by $35 \%$ (from 3280 to $2120 \mathrm{MPa}$ ), TEA - by $46 \%$ (from 169 to $92 \mathrm{~J} / \mathrm{m}^{2}$ ). The elastic limit reduced by $38 \%$ (from 8.2 to $5.1 \mathrm{MPa}$ ). The limit of elastic deformation practically does not change and is $0.26-0.29 \%$. The strain at fracture increases by $5 \%$, having a maximum of $4.66 \%$ at a $T S I_{\mathrm{MD} / \mathrm{CD}}$ of 3.29 , and then decreases to $4.37 \%$.

Fig. 6 shows the relative change in the main deformation characteristics of the samples depending on the degree of anisotropy according to $T S I_{\mathrm{MD} / \mathrm{CD}}$. Values for samples with minimal anisotropy are taken as $100 \%$. As it is shown in fig. 6, when the degree of stiffness anisotropy $-T S I_{\mathrm{MD} / \mathrm{CD}}$ rose, the stiffness and strength characteristics of the samples increased in the MD and decreased in the CD.

Dependencies shown in fig. 6 are non-linear. For the TSI value, which characterizes the elasticity and stiffness of the material, the rigidity (curve 1), and the breaking length, which characterizes the strength (curve 2), the increase in characteristics in MD and their decrease in the CD slows down in specimens with high anisotropy. This is explained by the predominant contribution of the fibers themselves to the mechanical behavior of the sample in the MD and interfiber bonds in the transverse direction. With a strong orientation of the fibers, close to orthotropy, the influence of the degree of anisotropy decreases. At a low degree of fiber orientation, on the contrary, it is of key importance.

The change in the value of the TEA (curve 3), which characterizes the dynamic strength of the sample, is determined by the simultaneous change in strength and elongation. Therefore, in the MD, the stabilization of its value is observed at high anisotropy, and the decrease in the $\mathrm{CD}$, is observed.

\section{Conclusion}

When optimizing the forming mode, it is necessary to take into account the simultaneous and multidirectional change of the paper properties in the MD and CD.

By increasing the degree of fiber orientation in the structure of paper from kraft softwood pulp, it is possible to increase the strength by $55 \%$, tensile stiffness by $63 \%$ while reducing the extensibility by $10 \%$ in the MD. Dynamic strength, as measured by the TEA failure performance, increased by almost $50 \%$. 
In the $\mathrm{CD}$, on the contrary, by increasing the degree of fiber orientation, it is possible to decrease the tensile stiffness by $33 \%$, decrease the strength by $55 \%$, and increase the extensibility by $5 \%$.

Due to the variation of the forming parameters, the established quantitative regulations allow optimizing the values of the deformation and strength properties of paper and their ratio in the MD and $\mathrm{CD}$.

\section{REFERENCES}

1. Beloglazov V.I., Komarov V.I., Gurjev A.V. Anisotropy of Deformational and Strength Characteristics of Kraft-Liner. Lesnoy Zhurnal [Russian Forestry Journal], 2005, no. 5, pp. 113-118. URL: http://lesnoizhurnal.ru/upload/iblock/513/513fd048ed1675b4a8742e24c d337e24.pdf

2. Hansson M.T., Rasmuson A. Finite Element Analysis of Three Dimensional Fibre Networks. Nordic Pulp and Paper Research Journal, 2004, vol. 19, iss. 1, pp. 105-111. DOI: https://doi.org/10.3183/npprj-2004-19-01-p105-111

3. Horng A.J., Fletcher R.S., Mickleborough C.L., Sasaki K.R. A Novel Use of the Dynamic Sheet Former in Paper Recycling: Simulates the Function of New Recycling Devices. Pulp and Paper Canada, 1996, vol. 97, iss. 12, pp. 135-137.

4. Kazakov Y.V. Practice of Using of Deformation Characteristics for an Estimation of Paper and Cardboard Quality. The Issues in Mechanics of Pulp-and-Paper Materials: Proceedings of the 1st International Conference. Arkhangelsk, NArFU, 2011, pp. 88-94.

5. Kazakov Y.V. The Structure and Properties of Laboratory Anisotropic Samples of Pulp and Paper Materials. Tsellyuloza. Bumaga. Karton, 2013, no. 6, pp. 56-60.

6. Kazakov Y.V. Kinetics of Deformation of Pulp and Paper Materials at Tensile Test. The Issues in Mechanics of Pulp-and-Paper Materials: Proceedings of the 5th International Conference in Memory of Professor Valery Komarov. Arkhangelsk, NArFU, 2019, pp. 23-31.

7. Kazakov Y.V., Koncevaya V.I. Mechanics of Anisotropic Laboratory Hand-Made Samples of Pulp-and-Paper Materials. The Issues in Mechanics of Pulp-and-Paper Materials: Proceedings of the 2nd International Conference in Memory of Professor Valery Komarov. Arkhangelsk, NArFU, 2013, pp. 201-207.

8. Kazakov Y.V., Romanova A.N., Chukhchin D.G. Effect of Fiber Orientation Anisotropy on the Paper Deformation Properties. The Issues in Mechanics of Pulp-and-Paper Materials: Proceedings of the 3rd International Conference in Memory of Professor Valery Komarov. Arkhangelsk, NArFU, 2015, pp. 298-303.

9. Kazakov Ya.V., Komarov V.I. The Software of the Laboratory Test Complex for the Deformability and Strength Evaluation of Pulp and Paper Materials (KOMPLEX). Certificate of the Computer Software Official Registration No. 2001610526, 2001. 1 p.

10. Komarov V.I. Analysis of the Stress-Strain Relationship under Tensile Testing of Pulp and Paper Materials. Lesnoy Zhurnal [Russian Forestry Journal], 1993, no. 2-3, pp. 123-131. URL: http://lesnoizhurnal.ru/upload/iblock/ef4/123_130.pdf

11. Komarov V.I., Beloglazov V.I., Gurjev A.V., Sysoeva N.V. Study of the Factors Influencing the Anisotropy of Tensile Stiffness of Cardboard Liner. Tsellyuloza. Bumaga. Karton, 2005, no. 7, p. 48.

12. Komarov V.I., Kazakov Y.V. Analysis of Mechanical Behavior of Pulp and Paper Materials under Tensile Load. Lesnoy vestnik [Forestry Bulletin], 2000, no. 3(12), pp. 52-62.

13. Kulachenko A., Uesaka T. Direct Simulations of Fiber Network Deformation and Failure. Mechanics of Materials, 2012, vol. 51, pp. 1-14. DOI: https://doi.org/10.1016/j. mechmat.2012.03.010

14. Lindblad G., Fürst T. The Ultrasonic Measuring Technology on Paper and Board. Kista, Sweden, Lorentzen and Wettre, 2001. 98 p. 
15. Mourad S., Skali-Lami S., Trehoult C. Instability of the Flow in a Closed Cylindrical Cavity and in a Short-Dwell Cavity. Coating Conference Proceedings. Toronto, 1999, pp. 447-455.

16. Romanova A.N., Kazakov Y.V. Measurement of Fiber Orientation Degree in Anisotropic Paper Structure. Actual Problems of Metrological Support for Applied Research Practice: Proceedings of the 2nd All-Russian Scientific and Technical Conference of Young Scientists, Postgraduate Students and Students. Arkhangelsk, NArFU, 2016, pp. 219-227.

17. Skowroński J.W. Modeling of Refining to Save Energy and Define the Impact of Refining Variables on Printability of Inkjet Paper. Part 3. Model to Predict Properties of Oriented Laboratory Sheets. Przeglad Papierniczy, 2011, vol. 67(10), pp. 625-631.

18. Tosto F.J., Chen J., Oliver J.F. Application of the Dynamic Sheet Former to Simulate Paper Grades Produced from Western Canadian Pulps. Proceedings of the Annual Meeting of the Pulp and Paper Technical Association of Canada, 2001, vol. 87, iss. B, pp. B31-B41.

19. Uesaka T., Juntunen J. Time-Dependent, Stochastic Failure of Paper and Box. Nordic Pulp and Paper Research Journal, 2012, vol. 27, iss. 2, pp. 370-374. DOI: https://doi.org/10.3183/npprj-2012-27-02-p370-374

20. Volkel H-G. Economical Lab-Sheet Forming Methods. Proceedings of the European Conference on Pulp and Paper Research: The Present and the Future. Stockholm, 1996, pp. 179-185.

21. Zhang F.-D., Pei J.-C., Li J., Liu W., Zhou C.-X. The Effect of Speeds of Jet and Wire on the Physical Properties of Paper Sheets Forming in a Dynamic Sheet Former. China Pulp and Paper, 2014, vol. 33(6), pp. 25-30.

Вклад авторов: Все авторы в равной доле участвовали в написании статьи Authors' Contribution: All authors contributed equally to the writing of the article 